\title{
Integrated Reservoir Study to Optimize Gas Production of Water Drive Gas Reservoir Case Study: Lower Menggala Gas Field
}

\author{
Panca Suci Widiantoro $^{1}$, Astra Agus Pramana ${ }^{2}$, Putu Suarsana ${ }^{3}$, Anis N. Utami ${ }^{4}$
}

\begin{abstract}
Production optimization in mature field water drive gas reservoir is not easy especially when water already breakthrough in producing wells. An integrated reservoir study is needed to get reliable strategy to optimize production of water drive gas reservoir.

This research presents the integrated reservoir study of Lower Menggala (LM) Gas Field which is located Central Sumatera Basin, Riau Province. LM had been produced since 1997, current RF are $55 \%$, which is quite high for water drive gas reservoir. The current gas rate production is about 1.97 MMscfd with high water production around 4250 BWPD, consequently some of wells suffered liquid loading problem

This research comprises of well performance analysis, estimate OGIP, aquifer strength of the reservoir by using conventional material balance method and modern production analysis method then conduct dynamic reservoir simulation to identify the best strategy to optimize gas production. Economic analysis also be performed to guide in making decision which scenario will be selected.

DST analysis on DC-01 well defined reservoir parameter, boundary and deliverability which are $\mathrm{P}^{*}=2520 \mathrm{psia}, \mathrm{k}=229 \mathrm{mD}$, Total skin $=8$, detected sealing fault with distance $175 \mathrm{~m}$, and AOF 45 MMscfd. Conventional material balance method gave OGIP 22.7 BScf, aquifer strength $34 \mathrm{~B} / \mathrm{D} / \mathrm{Psi}$, whereas modern production analysis estimated OGIP $22.35 \mathrm{BScf}$, aquifer strength $34 \mathrm{~B} / \mathrm{D} / \mathrm{psi}$. Those two method shows good consistency with OGIP volumetric calculation with discrepancy OGIP value $+/-1 \%$. Six (6) scenario of production optimization has been analyzed, the result shows that work over in two wells and drilling of 1 infill well (case 6) achieve gas recovery factor up to $75.2 \%$, minimal water production and attractive economic result.
\end{abstract}

Keywords - Aquifer Strengths, Economic, OGIP, Recovery Factor (RF), Water Drive Gas Reservoir

\section{INTRODUCTION}

$\mathbf{P}$ roduction optimization in water drive gas reservoir is not easy especially when water already break through in producing wells. An integrated production analysis is needed to get reliable strategy to optimize production of water drive gas reservoir.

${ }^{1}$ Manuscript received August 25th, 2017. This work was supported in part by PT Energi Mega Persada,Trisakti University, Pertamina University and SKK Migas.

${ }^{2}$ Panca Suci Widiantoro. Author is Sr Reservoir Engineer in Energi Mega Persada and Master of Petroleum engineering Trisakti University, Jakarta Indonesia(phone:+6282138578625,e-mail:pancasuciwidiantoro@gmail.com).

${ }^{3}$ Astra Agus Pramana. Author is with the Petroleum engineering Department, Pertamina University, Jakarta, Indonesia (phone: +62 8122287 3130, e-mail: agus.prama@gmail.com).

${ }^{4}$ Putu Suarsana. Author is with Magister Petroleum Engineering Department, Trisakti University, Jakarta, Indonesia, (phone: +62 811889229 , e-mail: ips3150@yahoo.com)

${ }^{5}$ Anis N Utami. Author is with SKK Migas, Jakarta, Indonesia, (phone: +62

8119200913, e-mail: Anutami@skkmigas.go.id)
Lower Menggala Gas Field is one of two gas field of EMP.

Malacca Straits SA located in Padang Island, Bengkalis Regency Riau Province. The location map shown in Figure 1. Lower menggala had been produced since 1997, when this study conducted the RF are $55 \%$, which is quite high for water drive gas reservoir. The current gas rate production is about 1.97 MMscfd with high water production around 4250 BWPD, consequently some of wells suffered liquid loading problem. The existing perforation in a bottom part mostly already below gas water contact. To optimize the production and increase RF of this reservoir need to conduct integrated production analysis which cover several analysis such as : well modeling analysis, modern production analysis, reservoir simulation and economic analysis.

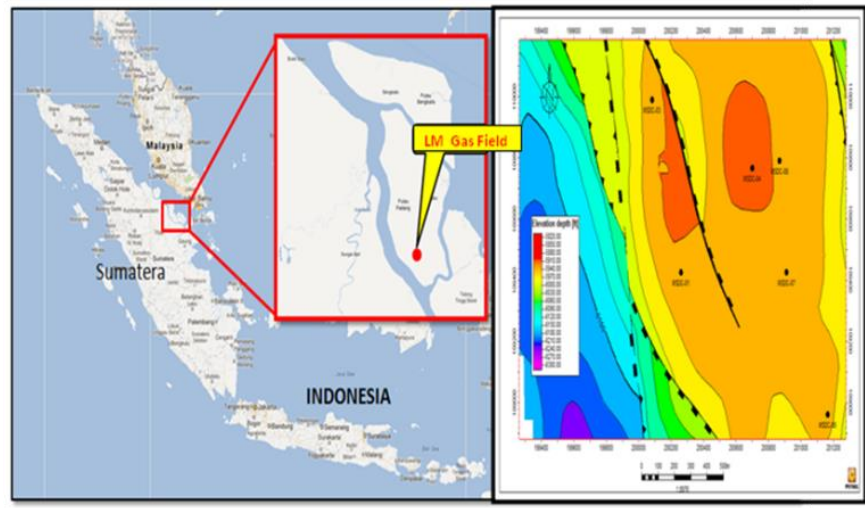

Fig.1. Lower Menggala Gas Field Location Map

This research presents the integrated Reservoir study and optimization of Lower Menggala (LM) Gas Field. The objectives of this research are:

1. To understanding performance of each well by conduct well testing interpretation and well performance analysis.

2. To estimate OGIP and aquifer strength of the reservoir by using conventional material balance method and modern production analysis method.

3. To construct dynamic reservoir model on latest production data and conduct history matching to tested the model whether it represent field behavior.

4. To predict future field performance to find out an optimal development plan to optimize gas production of the field.

5. To identify the best strategy to optimize gas production of this field which consider operational aspect, technical aspect and also economic wise. 


\section{MethodOLOGY}

Several task work will be performed during this research as listed below:

1. Data acquisition and selection

Collect well testing and or DST data, daily wellhead pressure and gas rate data from the beginning of production, as well as static data like initial reservoir pressure and temperature, rock properties, gas properties, open-hole logs ,well completion diagram and economic input data.

2. Data validation

Make sure all the dynamic data is valid. For example, if wellhead pressure increases, the gas rate should decrease. This step often takes the longest time, and involves much detective work to chase down the reason for step-changes and other anomalies. It is critical because "rubbish in equals rubbish out".

3. Well Modeling

First of all conduct well testing analysis to get reservoir pressure initial, reservoir parameter of tested well such as permeability, skin and possible reservoir boundary. The result then use as input for gas deliverability analysis to get IPR curve and AOF.

4. Material Balance Analysis

In this step, the production data and limited static reservoir pressure data will be analyzed using material balance analysis to get OGIP and aquifer strength parameter of the reservoir.

The material balance is expressed in reservoir volume of production, expansion and water influx as [1]

$$
\mathrm{GB}_{\mathrm{g}}+\mathrm{W}_{\mathrm{p}} \mathrm{B}_{\mathrm{w}}=\mathrm{G}\left(\mathrm{B}_{\mathrm{g}}-\mathrm{B}_{\mathrm{gi}}\right)+\mathrm{GB}_{\mathrm{gi}} \frac{\left(\mathrm{c}_{\mathrm{w}} \mathrm{s}_{\mathrm{wc}}+\mathrm{c}_{\mathrm{f}}\right)}{1-\mathrm{S}_{\mathrm{wc}}} \Delta \mathrm{P}+
$$

$\mathrm{W}_{\mathrm{p}} \mathrm{B}_{\mathrm{w}} \quad \ldots .(1)$

Production $=$ Gas Expansion + Water Expansion and or pore compaction + Water influx

$F=G\left(E_{g}+E_{f w}\right)+W_{e} B_{w}$

In most practical cases Efw $<<\mathrm{Eg}$ and may be omitted but not before checking that this is a valid neglect of the term across the entire range of pressure depletion. The material balance then become (Craft, et. al., 1991);

$F=G E_{g}+W_{e} B_{w}$ or $\frac{F}{E_{g}}=G+\frac{W_{e} B_{w}}{E_{g}}$

Schilthuis (1963) proposed that for an aquifer that is flowing under the steady-state flow regime, the flow behavior could be describe by Darcy's equation. The rate of water influx ew can be determined by applying Darcy's equation [1]:

$\frac{d W_{e}}{d t}=e_{w}=\left[\frac{0.00708 k h}{\mu_{w} \ln \left(\frac{r_{a}}{r_{\mathrm{e}}}\right)}\right]\left(p_{i}-p\right)$

The above relationship can be more conveniently expressed as:

$\frac{d W_{e}}{d t}=e_{w}=C\left(p_{i}-p\right)$

5. Modern Production Analysis using Type curve matching (Blasingame)

Modern Production Data Analysis is a method to evaluate the reservoir using combined rate and pressure data without the need to shut in wells. This analysis is able to estimate hydrocarbon in place, aquifer strength, with flowing material balance and other modern techniques. Reservoir characteristics, such as permeability and skin factor can also be determined by using type curves. Figure 2 shows the integration of knowledge of Modern Production Analysis.

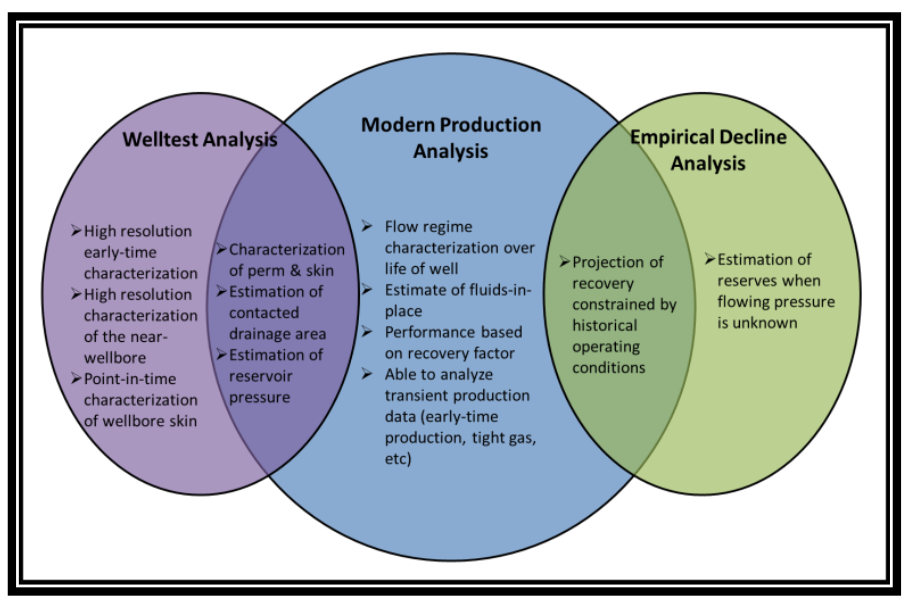

Fig.2. Integration of Knowledge of Modern Production Analysis [8]

Figure 3 shows the Type curve matching (Blasingame) which able to analysis reservoir performance.

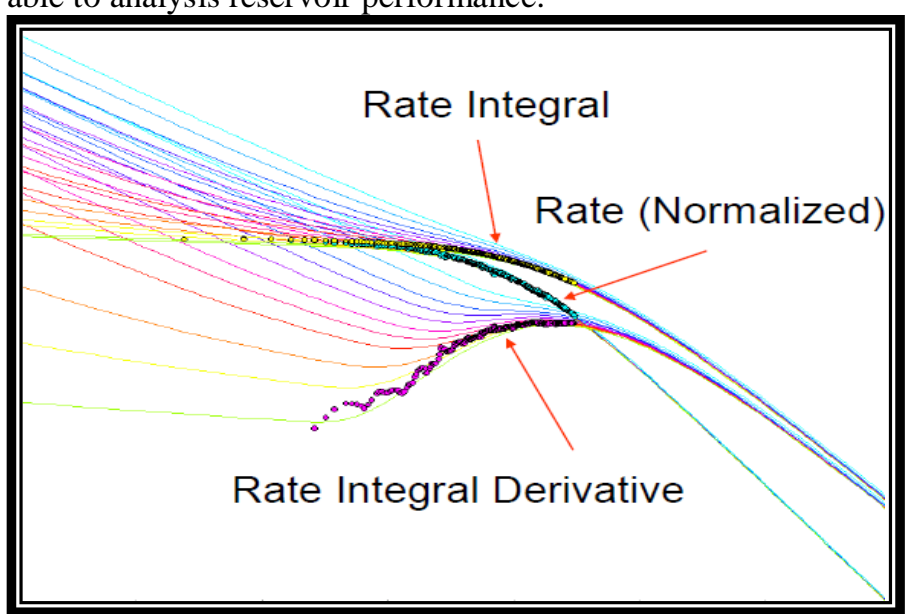

Fig.3. Rate Integral and Rate Integral Derivative [8]

In this step, the production data will be matched with the type curve. As well as an OGIP and aquifer strength estimate, type curves also confirm whether the reservoir is in transient or boundary-dominated flow. This is a useful quality-control, because all these techniques only work with boundarydominated flow. Those two analysis (in step 4 and 5) are useful to validate OGIP static model. The OGIP value of those two analysis then compare with OGIP from reservoir static model. The OGIP value should be in a good agreement with difference $<5 \%$.

6. Dynamic reservoir model/ Reservoir simulation

Reservoir simulation is a commonly used tool in the gas and oil field development. It helps engineers to simulate their recovery techniques before implementing them on the original field. It is multi-disciplinary and incorporates effort from 
geophysics, petrophysics, reservoir, production and facilities engineering.

Reservoir simulation comprise of several step: up scaling, initialization, history matching and prediction/forecasting. Reservoir simulation will generate several forecast scenario and a development plan will be prepared to ensure gas deliverability.

7. Economic evaluation

Economic evaluation will be run for each scenario then rank based on economic indicator result, the best economic result will selected as recommendation. This step guide in making decision which scenario will be selected.

\section{RESULT}

\section{A. Well Modeling}

The type of well testing which conducted in this well was DST. In Log-log plot (figure 4) clearly identified three time region: early, middle and late. In early time region data were very limited due to DST in this well were using subsurface valve to close and open the well, hence wellbore storage effect were minimal. After early time appear hump on the plot, it is indicated skin factor on this well. In Middle time region was appear radial flow, in this period several reservoir parameter were interpreted such as: $\mathrm{P}^{*}$ (P initial reservoir) 2520 psia, Permeability $229 \mathrm{mD}$, and total skin factor 8 (mechanical skin 3 , whereas geometrical skin 5). In term of skin factor there were 2 value mechanical and geometrical. Geometrical skin happened due to this well perforated partially $60 \mathrm{ft}$ of $117 \mathrm{ft}$, hence the analysis were using vertical-limited entry model. After radial flow period finished then follow by increasing derivative curve, it is strong indicated transient pressure response already achieve boundary. In other hand late time region already detected in this MSDC-01 DST. A sealing one fault model was selected as a best match to the raw data of MSDC-01 DST. Based on match model detected distance to boundary (sealing fault) was $175 \mathrm{~m}$.

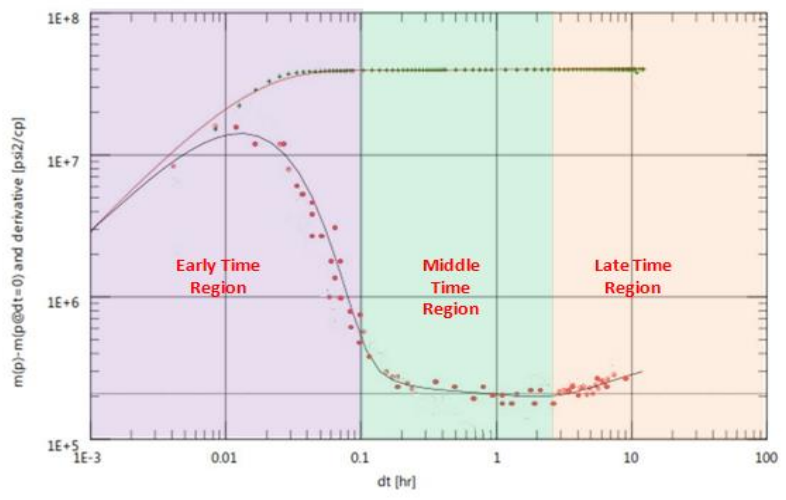

Fig.4. Well test Interpretation of DC-01 well

\section{B. Material Balance Analysis}

As there were limited static reservoir data available in LM gas reservoir. However, in this study material balance analysis also conducted. Driving mechanism in LM gas field is believed as strong water drive, its proved by plot of $\mathrm{p} / \mathrm{z}$ against the cumulative produced gas in figure 6 . The Material Balance $\mathrm{p} / \mathrm{z}$ plot shows deflection from straight line (see red dashed line), it's clearly indicated presence of aquifer support during gas depletion (see blue line), hence this method not applicable to estimate OGIP. The prediction would definitely be too optimistic if the OGIP is determined solely by extrapolating the $\mathrm{p} / \mathrm{z}$ data.

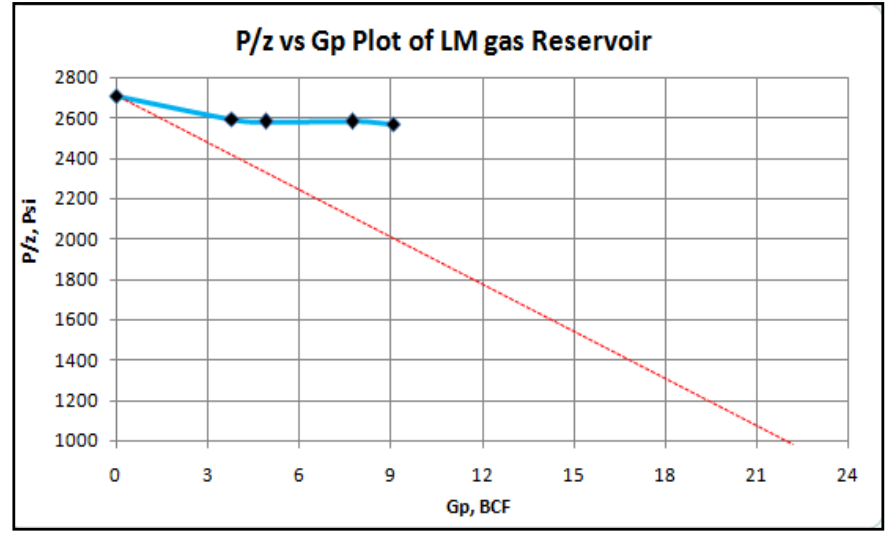

Fig.5 The Material Balance p/z Methods Indicated Aquifer Support

As previously described in methodology, when $\mathrm{p} / \mathrm{z}$ method not working, Havlena-Odeh is the best method to estimate OGIP incorporated with water influx of water drive gas reservoir. In this study M-BAL software are used for the analysis. Figure 6 shows the result Havlena-Odeh plot with Schilthuis aquifer model.

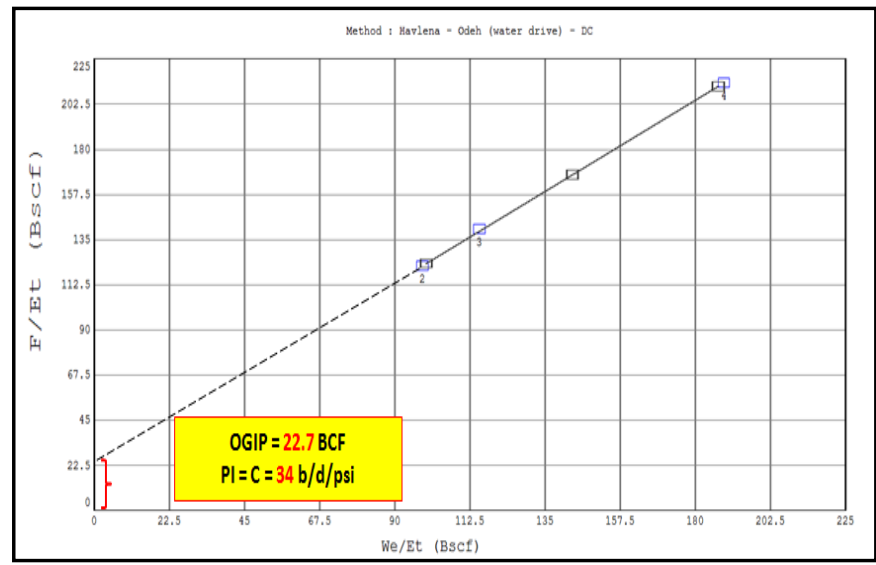

Fig.6. The Material Balance Havlena-Odeh estimates OGIP 22.7 BCF and Aquifer strength $34 \mathrm{~B} / \mathrm{D} / \mathrm{Psi}$

\section{Modern Production Analysis}

Modern Production Data Analysis is a method to evaluate the reservoir using combined rate and pressure data without the need to shut in wells. Since the LM gas field has good monitoring production data, so in this study also conducted Modern Production Analysis using Type curve matching (Blasingame). This analysis aimed to increase the confidence level of OGIP and Aquifer strength estimation. The plot of 
production monitoring data on Blasingame type curve presented in Figure 7. As we can see in figure 7, production monitoring data perfectly matched with Blasingame Type curve. The data dominantly laid on boundary dominated flow, hence OGIP value can be estimated confidently. Based on the above Blasingame type curve matching OGIP and Aquifer strength are $22.35 \mathrm{BCF}$ and $34 \mathrm{~B} / \mathrm{D} / \mathrm{Psi}$ respectively.
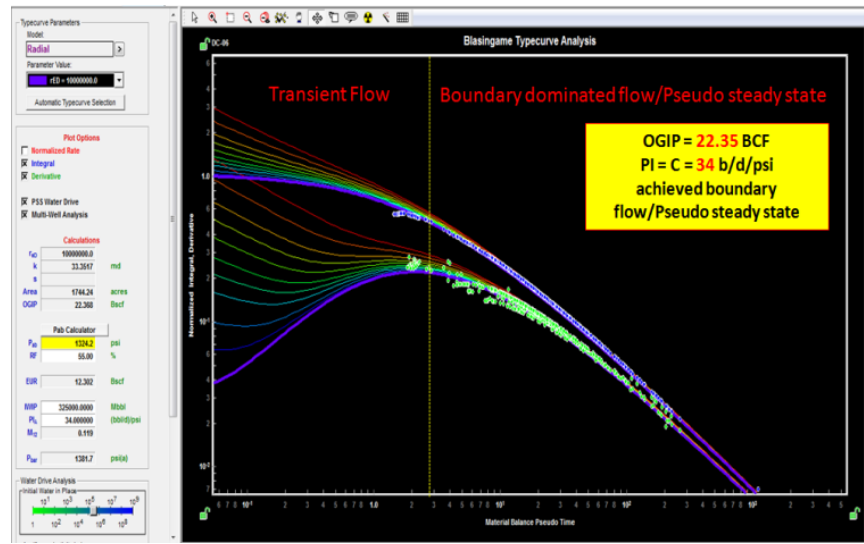

Fig. 7. The Blasingame Type curve matching estimates OGIP 22.35 BCF and Aquifer strength $34 \mathrm{~B} / \mathrm{D} / \mathrm{Psi}$

Table 1 presented OGIP and aquifer strength comparison several method which already discussed in previous section. Based on the comparison on the table below, OGIP value all those methods shows good agreement with discrepancy only 1 $\%$ respect to volumetric OGIP of static model. In other hand OGIP value from previous Integrated reservoir study 2009 are still valid, hence static model can be used for dynamic reservoir simulation. In term of aquifer strength, Material balance Havlena-Odeh and Blasingame Type Curve matching shows good consistency.

Table 1 OGIP and Aquifer Strength Comparison

\begin{tabular}{|l|c|c|c|}
\hline \multicolumn{1}{|c|}{ Parameter } & $\begin{array}{c}\text { Volumetric } \\
\text { (Static model) }\end{array}$ & $\begin{array}{c}\text { Material } \\
\text { Balance } \\
\text { (Havlena -Odeh) }\end{array}$ & $\begin{array}{c}\text { Modem } \\
\text { Production } \\
\text { Analysis }\end{array}$ \\
\hline OGIP (BCF) & 22.5 & 22.7 & 22.35 \\
\hline Aquifer strength (B/D/Psi) & - & 34 & 34 \\
\hline $\begin{array}{l}\text { Different OGIP respect to } \\
\text { volumetric (\%) }\end{array}$ & - & $+1 \%$ & $-1 \%$ \\
\hline
\end{tabular}

\section{Dynamic Reservoir Model/Reservoir Simulation}

Data input to Petrel RE or Eclipse was taken from all the analysis conducted and explained in the previous section. Dynamic reservoir model/ simulation grid was created with dimension 71 × 57 × 80 or 323,760 cells, grid size 50 x 50 m, and 80 layers. Reservoir simulation comprise of three section; initialization, history matching and prediction.

\section{- Initialization}

The gas saturation distribution in 3D model view and the cross section of LM reservoir at the initial condition is shown in Fig. 8

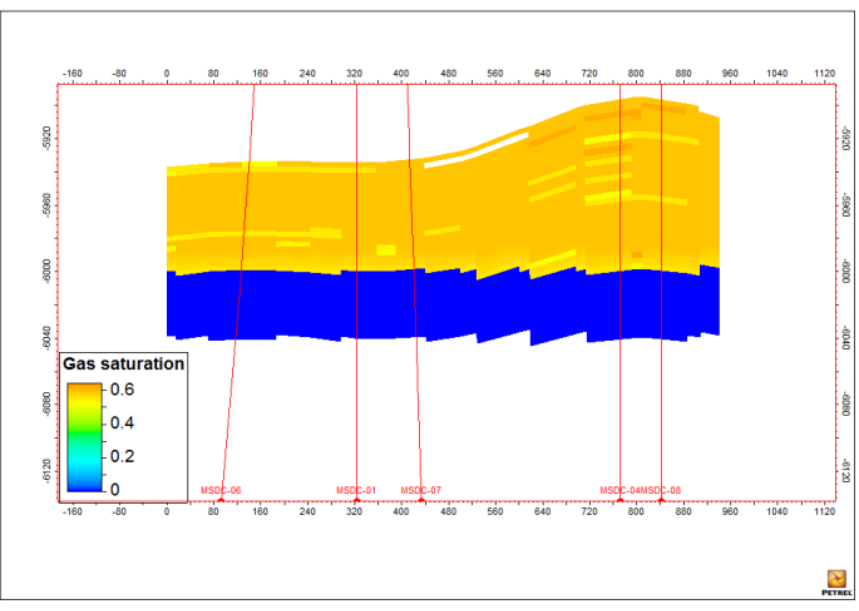

Fig. 8. The Gas Saturation Distribution At Initial Condition (x-section view North- South direction)

\section{- History matching}

This section showed the history matching of the simulation model with the aims of confirming the initial reservoir conditions and obtaining an acceptable match of the observed reservoir behavior. History matching analyses are performed to check the reliability of model in dynamic condition. To achieve the accurate history matching results, the simulation model was run based on the available data (Up to December 2015). It was observed that the field gas production rate match was excellent. Field water production rate match was moderate good. Reservoir pressure measurements were very few and showed pretty good match. The set of graphs comparing the simulation model (presented as line) results with measured data (presented as point/dot) were presented in figure 9 and gas saturation distribution in 3D model at end of history matching (December 2015) as presented in figure 10

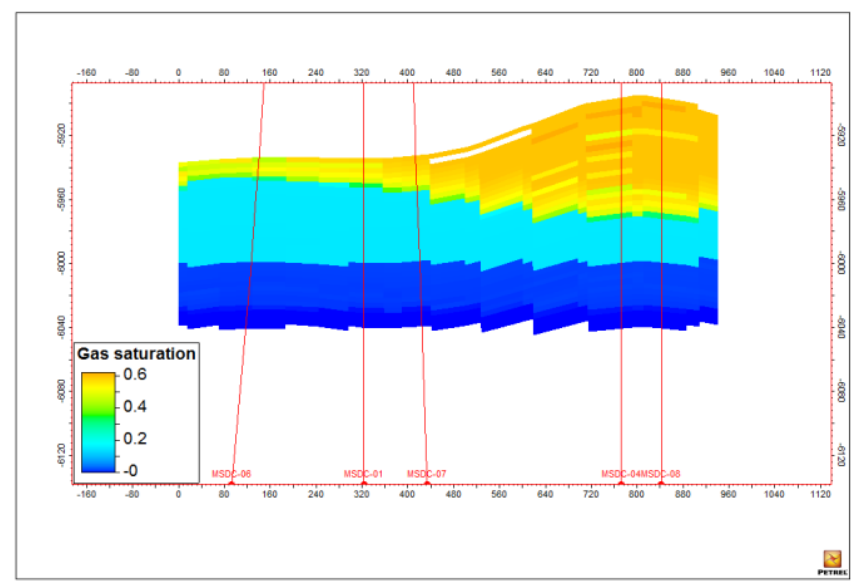

Fig. 9. The Gas Saturation Distribution at End of History Matching (x-section view North- South Direction) 


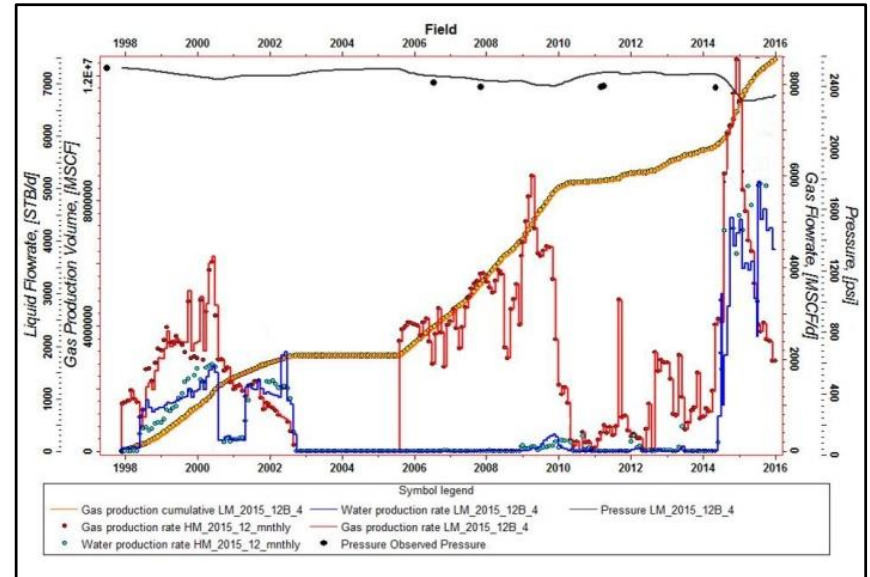

Fig.10. Field Gas rate, Gas Cum, Water rate, And Reservoir Pressure History Match.

\section{- Prediction}

This section focused the prediction of the future field/reservoir performance. To obtain the perfect scenario to optimize production of the field, a total number of 6 (six) different forecast cases were run up to December 2024. The forecast cases considered were as follows:

Case 1: Base Case or No Further Action (NFA)

Case 2 : Install low pressure compressor

Case 3 : Work over 2 wells

Case 4 : Add 1 infill drilling well

Case 5 : Combination Scenario 2 and 3

Case 6 : Combination of Scenario 3 and 4

Figure 11 and 12 presented the result of case 1 (Base Case) and 6 respectively.

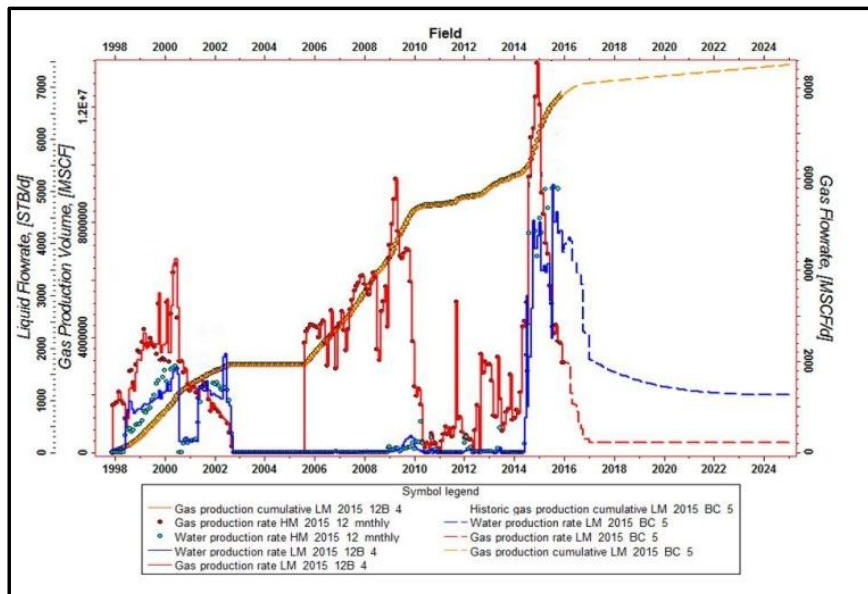

Fig. 12 Performance Prediction of Case 1: No Further Action (NFA)

Table 2 listed the result of Case 1-6.

Based on RF comparison above case 6 is the best case. To select the best scenario economic evaluation of each scenario will be consider.

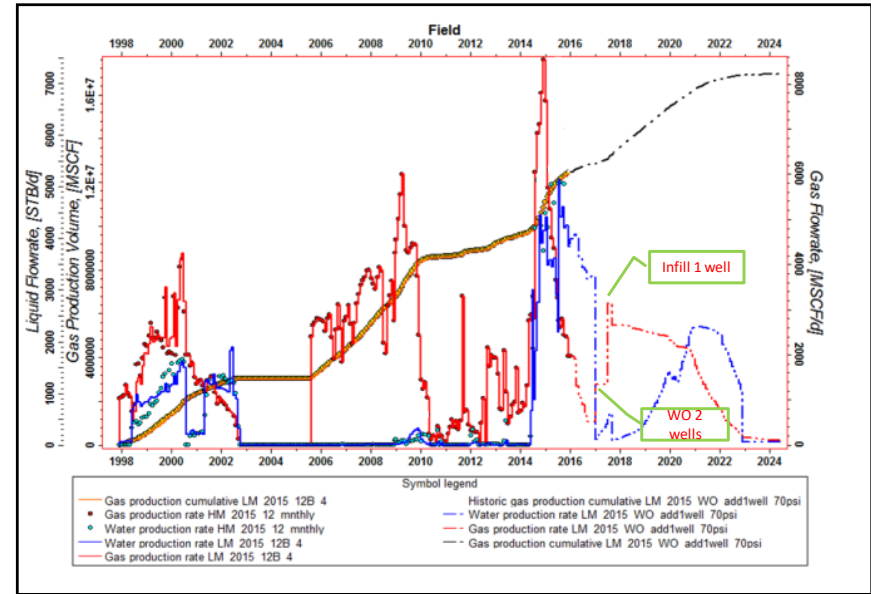

Fig. 8. Performance Prediction of Case 6 : Combination of Case 3 and Case 4

\begin{tabular}{|c|c|c|c|c|c|c|}
\hline $\begin{array}{l}\text { Predictive } \\
\text { Case }\end{array}$ & Definition & $\begin{array}{l}\text { OGIP } \\
\text { (BScf) }\end{array}$ & $\begin{array}{c}\text { Peak gas } \\
\text { prod } \\
\text { (MMScfD) }\end{array}$ & $\begin{array}{c}\text { Peak } \\
\text { water } \\
\text { prod } \\
\text { (STB/D) }\end{array}$ & $\begin{array}{l}\text { cum gas } \\
\text { production } \\
\text { (BScf) }\end{array}$ & $\mathrm{RF}$ \\
\hline Case 1 & No Further Action (NFA) & \multirow{6}{*}{22.5} & 0.3 & 1566 & 13.47 & $59.87 \%$ \\
\hline Case 2 & $\begin{array}{l}\text { Install low pressure } \\
\text { compressor }\end{array}$ & & 1.2 & 3234 & 14.85 & $66.0 \%$ \\
\hline Case 3 & Workover 2 wells & & 1.35 & 478 & 15.13 & $67.2 \%$ \\
\hline Case 4 & Drilling 1 infill well & & 2 & 2561 & 16.75 & $74.4 \%$ \\
\hline Case 5 & $\begin{array}{l}\text { Combination of Scenario } 2 \\
\text { and } 3\end{array}$ & & 2 & 1128 & 15.94 & $70.8 \%$ \\
\hline Case 6 & $\begin{array}{l}\text { Combination of Scenario } 3 \\
\text { and } 4\end{array}$ & & 2.89 & 2100 & 16.93 & $75.2 \%$ \\
\hline
\end{tabular}

\section{E. Economic Evaluation}

In determining the economic feasibility of each oil development cases, net present value (NPV), with $10 \%$ interest rate will be used as the main indicator. The following cost and condition assumption will be used to conduct the economic analysis :

$\begin{array}{llll}\text { Drilling Cost/well } & = & 4.5 & \text { MMUS\$ } \\ \text { Workover cost/well } & = & 353 & \mathrm{kUS} \$ \\ \text { Opex / year } & = & 531 & \mathrm{kUS} \$ \\ \text { Gas price } & = & 8.74 & \text { \$MMBTU } \\ \text { Compressor } & = & 1231 & \mathrm{kUS} \$ \\ \text { Maint. Comp } & = & 49 & \mathrm{kUS} \$\end{array}$

To generate economic calculation the PSC rule for gas project is applied for split calculation between government and PSC. The following term and condition is applied:

$\begin{array}{ll}\text { Contractor share after tax } & 35 \% \\ \text { Government share after tax } & 65 \% \\ \text { Contractor tax } & 44 \% \\ \text { First Tranche Petroleum (FTP) } & 20 \%\end{array}$

Economic analysis run was made for the performance prediction cases explained in the previous section. Table 3 presented economic comparison of each case. According to above table, case 6 showing best result. 
Table 3 Economic Comparison of Several Case Run

\begin{tabular}{|c|c|c|c|c|c|c|c|}
\hline \multicolumn{8}{|c|}{ Summary Result } \\
\hline \multirow[t]{2}{*}{ Parameter } & Cae 1 & Case 2 & Case 3 & Case 4 & Case 5 & Case 6 & \\
\hline & \multicolumn{7}{|c|}{ General Input } \\
\hline Initial Gas Rate & 0.2 & 1.1 & 1.1 & 1.0 & 1.7 & 1.8 MMSCFD & \\
\hline Gas Cum & 640 & 1,996 & 2,262 & 3,917 & $3,061 \mid$ & 4,085, MMSCF & \\
\hline Gas price (esc. $2 \%$ p.a) & 8.74 & 8.74 & 8.74 & 8.74 & $8.74 \mathrm{I}$ & 8.74 uss/MMBTU & \\
\hline CAPEX - Drilling cost & - & - & - & 4500 & & 4500 kuss & \\
\hline CAPEX - Facilities cost & - & 1,231 & - & 0 & 1,231 & ol kuss & \\
\hline OPEX - Workover Cost & - & - & 706 & - & 706 & $706 \mid$ kuss & \\
\hline OPEX cost & 531 & 580 & 531 & 531 & 580 & 531 | kUS\$/year & \\
\hline Gross Rev. & 7312 & 22,289 & 25,586 & 43,919 & 34,147 I & 44,891, kUS\$ & \\
\hline Cost Recovery & 1415 & 5,870 & 4,951 & 10,089 & $6,576 \mid$ & 10,503 kUSs & \\
\hline \multicolumn{8}{|l|}{ Government share } \\
\hline - Gov. income & 4128 & 10,672 & 13,413 & 22,863 & 17,921 | & 23,093 kUS $\$$ & \\
\hline -NPV @ 10\% disc, rate & 2709 & 7,734 & 9,091 & 15,652 & 12,847 & 16,988 | kUS\$ & \\
\hline Unrecovered cost & - & - & - & & & - kUS\$ & \\
\hline \multicolumn{8}{|l|}{ Contractor share } \\
\hline - Cont. income & 3184 & 11,617 & 12,173 & 21,056 & 16,226 I & 21,798 kUSs & \\
\hline- IRR & $>100 \%$ & $>100 \%$ & $>100 \%$ & $>100 \%$ & $>100 \%$ | & $>100 \%$ & \\
\hline -POT & - & - & - & 0.6 & & $0.03 \mathrm{l}$ Year & \\
\hline - NCF- Net Cashflow & 1769 & 5,747 & 7,222 & 12,311 & 9,650 | & 12,347 l kuss & \\
\hline - NPV @ 10\% disc, rate & 1161 & 3,892 & 4,895 & 8,146 & 6,645 & 8,936 kUS\$ & \\
\hline
\end{tabular}

\section{CONCLUSION}

LM gas field is water drive gas reservoir with current RF about $55 \%$, an integrated production analysis and optimization had been conducted with conclusions as listed below:

1) DST analysis on DC-01 well defined reservoir parameter, boundary and deliverability which are $\mathrm{P}^{*}=2520$ psia, $\mathrm{k}=$ $229 \mathrm{mD}$, Total skin $=8$, detected sealing fault in north east with distance $175 \mathrm{~m}$, and AOF 45 MMscfd.

2) Conventional material balance method gave OGIP 22.7 BScf, aquifer strength $34 \mathrm{~B} / \mathrm{D} / \mathrm{psi}$, whereas modern production analysis estimated OGIP $22.35 \mathrm{BScf}$, aquifer strength $34 \mathrm{~B} / \mathrm{D} / \mathrm{psi}$. Those two method shows good consistency with OGIP volumetric calculation of previous static reservoir model $22.50 \mathrm{BScf}$ with discrepancy OGIP value $+/-1 \%$.

3) Dynamic reservoir model able to describe reservoir performance, by conducted history matching it was observed that the field gas production rate, water production rate, and reservoir pressure measurement was almost accurately matched.

4) The production optimization of LM gas field was achieved by using the dynamic reservoir simulation method . In this thesis work, 6 (six) different prediction cases were run up to December 2024 to optimize production. Case 6 is the best result with highest RF $75.2 \%$ and minimal water production.

5) Economic analysis was run for six (6) cases to guide in selecting the best case. Economic result suggested case 6 is the best result with highest value of contractor NPV 8.93 MMUS\$ and fastest POT 0.03 year.

\section{REFERENCES}

[1] Ahmed, Tarek H., Reservoir Engineering Handbook, 3th Edition, Texas : Gulf Publishing Company, 2006.

[2] Arcaro, D. P., Bassiouni, Z.: "The Technical and Economic Feasibility of Enhanced Gas Recovery in the Eugene Island Field by Use of the Coproduction Technique," JPT, May, 1987, pp. 585-590.

[3] Dake, L., The Practice of Reservoir Engineering. Amsterdam: Elsevier Publishing Company, 1994.

[4] El-Ahmadi, et all, "Overestimation of Original Gas in Place in WaterDrive Gas Reservoirs Due to a Misleading Linear p/z plot", presented at Canadian International Petroleum Conference, Canada, 2001.

[5] EMP Malacca Straits S.A Team, "Lower Menggala Integrated Reservoir Study Report", Jakarta, 2009.

[6] Gomaa, Ezzat, "Reliability \& Consistency of Core Analysis PVT Data", In-House Training Course, Jakarta, 2009.

[7] Mattax, Calvin C., Reservoir Simulation, USA: Society of Petroleum Engineer Inc., 1990

[8] Widiantoro, Panca S., and Hakim, Arif R., "Production Data Analysis Estimating OGIP and Forecasting Gas Production Profile From Rough Data of Over-Pressured Gas Reservoir", presented at APOGCE, Bali, 2015 .

[9] Wang, Sharon and Tunjar, Cesar, "Quickly Identifying Well Problem by Modern Production Analysis for a Better Stimulation Plan", SPE Production and Operation Symposium, Oklahoma, 2009, p.1-3. 